\title{
Beyond Broudy's Triad—Infusing University Students with the Love of Poetry
}

\author{
Mounir Ben $\mathrm{Zid}^{1}$ \\ ${ }^{1}$ English Department, College of Arts, Sultan Qaboos University, Oman \\ Correspondence: Mounir Ben Zid, Sultan Qaboos University, P.O. Box 42, PC 123, Al-Khoud, Muscat, Oman. \\ E-mail: mounir@squ.edu.om
}

Received: June 6, 2016

Accepted: December 30, 2016 Online Published: March 30, 2017

doi:10.5539/ies.v10n4p65

URL: https://doi.org/10.5539/ies.v10n4p65

\begin{abstract}
In spite of the diverse schools of thought providing guidance for poetry teachers - such as the didactic, heuristic, or phyletic approaches - this myriad of teaching modes has failed to generate adequate student appreciation for poetry courses. The reason for this is teachers' tendency to cling to the idea that one must choose a particular approach and find out the correct or fixed meaning. This study includes a recommendation for a major shift in teaching poetry that transforms each class session into a new learning rather than a teaching experience — one in which the instructor's role is to inspire a passion and love for poetry in ESL learners. This teaching-learning style requires that teachers change from being omniscient sages to participants, co-explorers, and learners-a move from teaching methods to learning styles and a shift from encouraging the love of teachers to inspiring the love of poetry in university students.
\end{abstract}

Keywords: didactics, heuristics, philetics, poetry, Sultan Qaboos University.

\section{Introduction}

The quandary of choosing the most effective teaching approach to increase students' knowledge has frustrated poetry teachers for years. This study arises from this perpetual frustration and includes guidance on an alternative direction which has received less scholarly attention than deserved. It must be emphasized at the outset, however, that the key concern of this study is not the controversy over the repertoire of teaching methods. As such, prior to portraying the myriad teaching methodologies, a distinction between teaching method and teaching style is necessary.

In his seminal article, "Beyond Didactics, Heuristics, and Philetics," Martinez-Brawley (1977) differentiated teaching method from teaching style. She pointed out that "a method is a modus operandi; it is a learnable way of doing something; it is an aid which a person utilizes to accomplish a task more expediently, economically and efficiently ... [it is] the result of rational choice from available alternatives" (p. 82). In her distinction between teaching method and teaching style, Martinez-Brawley further argued that teaching methods tend to be unstable and unpredictable, while teaching styles were more stable and predictable from knowledge of the teacher's personality, attitude, and values:

If a method becomes part and parcel of an individual's personality, whether it be teacher or therapist, it ceases to be a method. It becomes ego-syntonic, and consequently, a component of the person's characteristic style of behavior ... [thus] a style is a characteristic way of behaving ... it permeates the many roles an individual may perform in his social situation. It is contradictory to speak of choice in relation to styles, for if there were any choice it must have been done unconsciously and certainly not the result of rational examination. (Martinez-Brawley, 1977, p. 83)

With this in mind, the framework for analysis used in this study is based upon Broudy's (1972) theory of the paradigm of teaching, namely didactics, heuristics, and philetics. The "Broudy triad," a reconciliation of different modes of instruction, represents the basis of our teaching practices with the teacher reemerging as more than "a legalistic rule follower and learning technician" (Seckinger, 1982, p. 29). In like manner, the paper puts forward suggestions to go beyond the philetic method of teaching to propose a teaching style wherein the starting point for any conversation about poems is an attempt to instigate desire, feeling, appreciation, enjoyment, and love of poetry in ESL learners. 


\section{Broudy's Triad}

There are diverse schools of thought that might provide guidance for the teacher of poetry; each one is unique in what it offers in the curriculum. The act of teaching may be viewed from different perspectives and the precise method of teaching poetry is subject to interpretation and different philosophies of instruction. The multitude of prescriptions for the improvement of teaching, according to Broudy (1972), falls into three main categories: didactics, heuristics, and philetics. Overall, "Didactics asks the teacher to function as an efficient machine; philetics asks him to be a warm, sensitive, concerned person; heuristics demands intellectual security and flexibility (Broudy, 1972, p. 61).

The didactic method is based on a traditional pedagogy wherein knowledge is passed from teacher to students. Its aim is the transmission of knowledge and skill, wherein a poem is tortured for a confession of its singular meaning.

The heuristic or Socratic method of teaching refers to the "method of teaching that is designed to promote discoveries by the pupil" (Broudy, 1971, p. 1); it is intended to stimulate creativity and problem-solving situations wherein students are not blank slates but rather thoughtful and knowledgeable human beings able, with proper guidance, to explore poems on their own.

The philetic style involves the teacher being in a relationship of loving concern in a community of learners, "urg[ing] that the secret of successful teaching is love - the love of the teacher by the learner and presumably vice versa (Broudy, 1971, p. 4). Central to this teaching-learning style is a less empirically founded continuum, which suggests a sequence rather than the hopscotch movement as an archetypal teacher's response to classroom situations in everyday teaching.

\subsection{The Didactic Method: Teaching to Torture a Confession from a Poem}

I ask them to take a poem and hold it up to the light like a color slide [...] But all they want to do is tie the poem to a chair with a rope and torture a confession out of it. (Collins, 1988, p.15)

In the majority of discussions about poetry with students at the university, most instructors assume a leadership role, setting the focus of the discussion and determining both specific questions and probes. Although this didactic pattern can be used effectively, in the end there is little time for student response and thus less opportunity for students to engage in extended and connected interactions.

When inhabiting the didactic mode in teaching poetry, teachers tend to focus on transmitting facts, ideas, and values through mastering knowledge. The underlying concept of this teacher-centered approach a one-way movement of knowledge from teacher to students; subjects, standards, and methods are determined by the teacher. The major aim of this approach is to transmit values and stress that students accomplish the goals set by their teachers. In accordance with this teaching form, instructors inculcate the "correct" interpretation of poems, identifying a central theme and the author's intent, while the students are transformed into passive receptors of information.

The didactic approach is sometimes efficient since it structures the teaching content in a systematic way. This approach is appropriate when teachers want to treat all students equally and transmit the course contents in the most direct way possible. With this mode of teaching, the teacher may modify the course contents to teach systematically and completely, preparing carefully organized teaching plans that specify teaching purposes, materials, methods and goals, and consequently, the teacher's intents are well transmitted to students. Other advantages of the didactic method include the fact that many students feel secure with a specified schedule of academic assignments, and teachers can use their didactic preparation to transmit knowledge to their students and thus anticipate what is going to happen in the classroom.

Yet, the didactic approach has the serious drawback of ignoring or diminishing individual, independent learning or of backgrounding the students' life experiences. More important, this approach tends to kill students' passion for poetry, categorize and stereotype students, and denigrates the students' differences in the learning ability, interests, and ideas. One more drawback of the didactic method is that students often express boredom, disinclination, and lack of motivation in the subject matter.

\subsection{The Heuristic Method of Teaching Poetry: Learners as Co-Creators}

Then said a teacher, "Speak to us of Teaching." And he said: No man can reveal to you but that which already lies half asleep in the dawning of our knowledge. The teacher who walks in the shadow of the temple, among his followers, gives not of his wisdom but rather of his faith and his lovingness. If he is indeed wise he does not bid you enter the house of wisdom, but rather leads you to the threshold of your own mind. (Gibran, 1923, p. 58). 
The heuristic or Socratic method of teaching moves to a learning paradigm in which teachers produce learning through student questioning, discovery, and construction of knowledge. Such transition in the focus of instruction from teaching to learning, as viewed by Collins and O'Brien (2003), is a learning model that places the student in the center of the learning process and where "the instructor provides students with opportunities to learn independently" (p. 3 ). In such an environment, learners are treated as co-creators in the learning process, as individuals with ideas and issues that deserve attention and consideration. This Socratic method of maieutics, figuratively referred to as midwifery, attempts to prove there is no such thing as teaching, that there is only remembering, and that "such a classroom does not require every student to think the same thoughts about the same books" (Auciello, 2000, p. 92).

Teaching poetry heuristically is to democratize classroom experiences and go beyond paper and pencil examinations to involve students' real, active, and practical participation in a curriculum. While the heuristic method, as perpetuated by the most recent descendants of the great teacher Socrates like John Dewey and Jean Piaget, helps students give birth to their own ideas and insights, it does show some weaknesses when carried into practice. It could be argued that, with the heuristic method, students who view teachers as authority figures may feel their security threatened when called upon to present materials of their own creation. Also, teachers may lose self-confidence and control of both the classroom and the subject matter.

\subsection{The Philetic Style: Teaching to Inspire the Love of Teachers}

The philetic style, as defined by Broudy (1972), is an act of love wherein the teacher's task is mainly to alleviate student's anxiety, fear, and insecurity: "engag[ing] in a kind of unlearning process in which barriers are removed from the inner self ... so that genuine healing can begin to take place" (p. 252).

Not only is the philetic learning paradigm student-centered, it is also process-oriented. This orientation assumes that an instructor begins with student needs and develops courses and assignments that speak to these needs while remaining open to adjustments in methods and schedules to ensure genuine student learning. In a similar process, the teacher is guided by questions, problems, and interests that students bring to the classroom that, in turn, enhance student motivation to learn, while giving the freedom to the teacher to make critical and creative curriculum decisions.

Additionally, the philetic style of teaching rests on a humanistic educational perspective that emphasizes students and teachers as authentic people who together build, maintain, repair, and promote effective and interpersonal relationships. This is not to suggest that teachers never lecture, but rather that their lectures are conversational, relatively brief, and linked to student application. At every stage of their teaching, they have to assume that learning is not just about know, but also about responding and doing. In other words, the teaching mode they should set out for their poetry classes is a continuum that is less empirically founded and suggests a sequence rather than the hopscotch movement as an archetypal teacher's response to classroom situations in everyday teaching. Rather than cling ing to one single method of teaching, their strategy should consist of a series of successive different encounters with the students.

The arguments above suggest that these encounters change and move gradually from teaching dissemination and minimal skills toward peripheral engagement and educational intimacy, until at last the teaching presence resides fully in the learner. In other words, the perspective instructors should take - that of a combination of teaching forms and modes - is marked by an increasingly rich encounter between teacher and learner until the distance is collapsed and the student is fully released to work on his or her own. This echoes Heidegger's (1968) definition of teaching where "To be a teacher is, above all, to let others learn" (p. 15).

Conceptually, each one of these stages or teaching forms has an independent existence with its own rhythm and set of inner dynamics. They can be interconnected, often overlapping, or strewn within each other. In a real teaching situation, however, one central form usually predominates depending on the particular stage of the pedagogical possibilities allowed by the class environment.

In comparison to the didactic approach, the philetic style of teaching, or rather learning, shifts to the student as learner and to the teacher as facilitator and guide. The teacher's task here is to help the student bring to fruition what already lies inside the mind and the heart. Thus, the teacher's overt activities decrease while those of the student gather momentum. The guiding principle of this teaching form is Galileo's famous dictum: "You cannot teach a man anything; you can only help him to find it within himself" (as cited in Kahle \& Robbins, 2004, p. 4).

In like manner, the teacher needs to change from an "all-knowing sage" to a participant in the exploration whose goal is to connect the learning about poetry to students' individual needs. The underlying advantage of the philetic pedagogy is that it humanizes education in an era of technocratic standardization, it views students as 
human beings and gives them a chance to explore their own personalities, independent and self-responsible learning. Another advantage of the philetic teaching method is that it liberates teachers and enables them to become human friends, helpers and facilitators of learning, it leads to a change of heart in both teachers and students, cultivates individual differences, and develops original thinking and independence of character.

Yet the philetic style has a few limitations. Among the major weaknesses of teaching in a philetic style is that the focus is on inspiring students to love their teachers and that subject matter tends to lose its objective and become arbitrary; cohesion of interests and perceptions among students are thus often difficult to create.

\section{Beyond Broudy's Triad: Inspiring the Love of Poetry in SQU Students}

The arguments ultimately show that the didactic, heuristic, and philetic have their place in the teaching of poetry. However, this teaching combination of styles will have to go beyond the confines of any method or teacher; they need not be what they previously have been to expose learners to a world in which methods of teaching are only means to an end. Therefore, a move from teaching methods to teaching styles and from encouraging the love of teachers to inspiring the love of poetry in ESL learners is the most ideal progression. Developing an enduring taste for poetry, then, is a key to helping students understand how literature relates to their world, appreciating and enjoying what they are exposed to.

To this end, a more helpful way to teach poetry is to create a better atmosphere of learning, arouse students' genuine interest, provide students with aesthetic pleasure, and enable them to appreciate and enjoy the beauty and musicality of words in poems. More importantly, this teaching-learning style should secure rapport with students, invite teachers to inspire the passion and love of poetry in their students, and help them not to lose the sense of wonder and enthusiasm that should be in the forefront of enjoying poetry.

Hence, it is the need of the time that, after they have an interest and desire for poetry, Sultan Qaboos University students can move to heavier tasks and discussions about poetry and how to further understand and analyze what is being portrayed. It is timely that the pendulum swung in support of the love of poetry as Jean Little seems to insinuate it in his poem "Alfred English Class":

I used to like "Stopping by woods on a Snowy Evening.

I liked the coming darkness,

The jingle of harness bells, breaking-and adding to

-the stillness,

The gentle drift of snow ...

But today, the teacher told us what everything stood for.

The woods, the horse, the miles to go, the sleep-

They all have "hidden meanings."

It's grown so complicated now that,

Next time I drive by,

I don't think I'll bother to stop (Little, 1986, p. 31).

\section{Conclusion}

Arguing against the practice of torturing a confession from a poem, this paper is not an attempt to negotiate through the disparities, find a common ground, or move towards a more widely-shared approach to the teaching of poetry. Instead, a teaching-learning style is most ideal, one with, at its core, a learning environment that brings together various types of teaching on a continuum that deepens the engagement between teacher and student and maximizes student learning.

Although the love of poetry should be given priority, there is no single royal road or optimum model to teach poetry and no single model "seems to cover all phases of a teacher's role in instruction classroom management, and personal relations" (Broudy, 1972, p. 257). Appropriateness of style is the key principle in thinking about the choice of instructional strategies and methods. It is the contention of this study that one approach, whether didactic, heuristic, or philetic, is not appropriate in all situations and cannot cover all of the complexities and idiosyncrasies of subjects and teaching situations. Deciding on whether to use a particular approach depends on many factors such as the classroom setting, teachers' educational convictions, their instructional purpose, the subject, and the teacher's observation of the classroom situation. 


\section{References}

Auciello, J. (2000). Chronicle of a battle foretold: Curriculum and social change. English Journal, 89(4), 89-96. https://doi.org/10.1002/9781444323566

Broudy, H. S. (1972). Didactics, heuristics, and philetics. Educational Theory, 22(3), 251-261. https://doi.org/10.1111/j.1741-5446.1972.tb00561.x

Collins III, J. W., \& O’Brien, N. P. (Eds.). (2003). Greenwood dictionary of education. Westport, CT: Greenwood.

Collins, B. (1988). The apple that astonished Paris. Fayetteville, AR: University of Arkansas Press.

Gibran, K. (1923). The prophet. New York, NY: Alfred A. Knopf.

Heidegger, M. (1968). What is called thinking? (J. G. Gray, Trans.). New York, NY: Harper and Row.

Kahle, P. A., \& Robbins, J. M. (2004). The power of spirituality in therapy: Integrating spiritual and religious beliefs in mental health practice. New York, NY: The Haworth Pastoral Press.

Little, J. (1986). Hey world, here I am! Toronto, OT: Kids Can Press.

Martinez-Brawley, E. A. (1977). Beyond didactics, heuristics, and philetics. Peabody Journal of Education, 54, 82-87. https://doi.org/10.1080/01619567709538111

Seckinger, D. S. (1982). Three dimensions of education. McGill Journal of Education, XVII(1), 23-29.

\section{Copyrights}

Copyright for this article is retained by the author(s), with first publication rights granted to the journal.

This is an open-access article distributed under the terms and conditions of the Creative Commons Attribution license (http://creativecommons.org/licenses/by/4.0/). 